\title{
Review: Make ruminants green again - how can sustainable intensification and agroecology converge for a better future?
}

\author{
B. Dumont ${ }^{1 \dagger}$, J. C. J. Groot ${ }^{2}$ and M. Tichit ${ }^{3}$ \\ ${ }^{1}$ Université Clermont Auvergne, INRA, VetAgro Sup, UMR Herbivores, 63122 Saint-Genès-Champanelle, France; ${ }^{2}$ Farming System Ecology Group, Wageningen \\ University \& Research, Wageningen 6700 AK, The Netherlands; ${ }^{3}$ UMR SAD-APT, INRA, AgroParisTech, Université Paris-Saclay, 75000 Paris, France
}

(Received 21 December 2017; Accepted 3 May 2018; First published online 24 August 2018)

Livestock farming systems provide multiple benefits to humans: protein-rich diets that contribute to food security, employment and rural economies, capital stock and draught power in many developing countries and cultural landscape all around the world. Despite these positive contributions to society, livestock is also the centre of many controversies as regards to its environmental impacts, animal welfare and health outcomes related to excessive meat consumption. Here, we review the potentials of sustainable intensification (SI) and agroecology (AE) in the design of sustainable ruminant farming systems. We analyse the two frameworks in a historical perspective and show that they are underpinned by different values and worldviews about food consumption patterns, the role of technology and our relationship with nature. Proponents of SI see the increase in animal protein demand as inevitable and therefore aim at increasing production from existing farmland to limit further encroachment into remaining natural ecosystems. Sustainable intensification can thus be seen as an efficiency-oriented framework that benefits from all forms of technological development. Proponents of AE appear more open to dietary shifts towards less animal protein consumption to rebalance the whole food system. Agroecology promotes system redesign, benefits from functional diversity and aims at providing regulating and cultural services. We analyse the main criticisms of the two frameworks: Is SI sustainable? How much can AE contribute to feeding the world? Indeed, in SI, social justice has long lacked attention notably with respect to resource allocation within and between generations. It is only recently that some of its proponents have indicated that there is room to include more diversified systems and food-system transformation perspectives and to build socially fair governance systems. As no space is available for agricultural land expansion in many areas, agroecological approaches that emphasise the importance of local production should also focus more on yield increases from agricultural land. Our view is that new technologies and strict certifications offer opportunities for scaling-up agroecological systems. We stress that the key issue for making digital science part of the agroecological transition is that it remains at a low cost and is thus accessible to smallholder farmers. We conclude that $\mathrm{SI}$ and AE could converge for a better future by adopting transformative approaches in the search for ecologically benign, socially fair and economically viable ruminant farming systems.

Keywords: ecosystem services, efficiency, food systems, redesign, sustainability

\section{Implications}

There are different futures for ruminant farming systems as regards to production scenarios, climate mitigation measures and food consumption trends. Sustainable intensification (SI) and agroecology (AE) are two frameworks that aim to design more sustainable systems. Here, we analyse them in a historical perspective and discuss how they have been applied to temperate and tropical ruminant systems. Although underpinned by different values pertaining to food consumption patterns, social equity, the role of technology and our relationship with nature, our view is that we should not

${ }^{\dagger}$ E-mail: bertrand.dumont@inra.fr be locked into a single approach, as SI and AE could converge for a better future.

\section{Introduction}

Livestock is a major component of rural economies, cultures and landscapes around the world. It provides multiple benefits such as the provision of protein-rich food from inedible resources, resulting in farm income and contributing to food security and employment. For instance, livestock products provide $22 \%$ of the dietary energy and $50 \%$ of protein consumption in Europe. The livestock sector contributes $€ 130$ billion annually to the European economy and creates employment for almost 30 million people (Animal Task Force, 
2013). In developing countries, livestock is important as capital stock. Cattle and buffaloes contribute to agricultural activities through draught power, utilise roughages and crop residues that are inedible by humans, and concentrate nutrients in manure for organic fertilisation. The cultural importance of livestock is reflected in the high status that is attached to cattle ownership. Herbivore farming systems also have 'secondary' effects or positive externalities such as contributions to landscape heritage, gastronomy and tourism in European grassland-based landscapes, South-American pampas and Mongolian steppes. Grassland-based landscapes and High Nature Value farmland are important for biodiversity conservation and provide key regulating and cultural services (Rodríguez-Ortega et al., 2014). Despite these positive contributions to society, livestock is also the centre of many controversies as regards to its environmental impacts, including land conversion and degradation. Livestock requires a large amount of feed resources (they use one-third of total cereal production and $8 \%$ of human water use; Makkar, 2018). Agricultural land-use to meet the demands for animal products has been noted as the main cause of deforestation; the most recent research shows that approximately two-thirds of the cleared areas in the Brazilian Amazon were converted to pastures (Guéneau, 2018). Livestock account for $14.5 \%$ of total greenhouse gas (GHG) emissions (Gerber et al., 2013), which makes the livestock sector a major contributor to climate change. Beef and dairy cattle contribute most to emissions, representing $65 \%$ of sector emissions, followed by buffaloes (Bubalus bubalis: $8.7 \%$ ) and small ruminants (6.7\%). Grassland-based systems, however, also contribute to carbon sequestration and thus were identified as a key option for mitigating climate change at the United Nation Climate Change Conference that was held in Paris in 2015. Finally, the whole livestock farming sector is currently facing changes in socio-cultural values related to animal welfare and knowledge of food origin.

Total demand for livestock products is expected to increase at a global scale (Campbell et al., 2014). Most of the increase in livestock feed demand will occur in developing countries, which already face many food security challenges (Makkar, 2018) and most of the land-use-related biodiversity impacts (Chaudhary and Kastner, 2016). Therefore, continued exploration of possibilities for increasing livestock production while decreasing the pressure on ecosystems is needed. There are different ways to achieve livestock farming sustainability that include notions or frameworks such as ecological or SI of agriculture, circular economy, industrial ecology, AE and organic farming. There is an ongoing debate whether land for nature and that for production should be segregated (land sparing) or integrated on the same area (land sharing). The first option calls for increasing the production of animal proteins from existing farmland, without further encroachment into remaining natural ecosystems, as many agricultural lands are assumed to not reach their full production potential (Foley et al., 2011; zu Ermgassen et al., 2018). This is the basis of SI that aims to spare land for nature, as most remaining potentially cultivatable land is beneath tropical forests, where conversion to agriculture is highly undesirable. This option implies that biodiversity in agroecosystems is functionally negligible (Tscharntke et al., 2012). An alternative option promotes a range of contextspecific ecosystem-based principles that stimulate natural processes to reduce dependence on chemical inputs and cut production costs. This is the basis of AE that can be seen as part of a land sharing approach with functional links with ecosystem services (Tittonell, 2014) and assigns equal importance to food production and ecosystem integrity (Dumont et al., 2013).

Sustainable intensification and $A E$ are thus two frameworks that promote ways to reconcile natural resource management and food production in the long term and under climate uncertainty. They have been seen as complementary steps away from industrial systems towards the necessary transition of agricultural and livestock production systems (Tscharntke et al., 2012; Dumont et al., 2013; Smith, 2013; Gordon et al., 2017; Makkar, 2018). However, other authors have stated that although $\mathrm{SI}$ is a step in the right direction, it mainly conforms to the current neoliberal agricultural model (Guéneau, 2018), and AE cannot co-exist alongside the aggressive expansion of industrial agriculture, genetically modified organisms and agrofuels (Altieri et al., 2017). According to Fouilleux et al. (2017), it is not necessary to endorse productionist agricultural models to feed the world's population. Agroecology would thus not need to be combined with any other approaches (Altieri et al., 2017). Our aim here is not to enter this type of controversy but rather to review the potentials of $\mathrm{SI}$ and $\mathrm{AE}$ to design sustainable ruminant systems. In the first two sections, we analyse $\mathrm{SI}$ and $\mathrm{AE}$ in an historical perspective, which reveals that $\mathrm{SI}$ is an efficiency-oriented perspective, while AE promotes system re-conception. Comparing $\mathrm{SI}$ and $\mathrm{AE}$ highlights a different role of nature in the design of agricultural and livestock farming systems (Tittonell, 2014). We also analyse the main criticisms of these frameworks: is SI sustainable? How much can AE contribute to feeding the world? In the final section, we summarise how $\mathrm{SI}$ and $\mathrm{AE}$ are underpinned by different values and worldviews (i.e., a structuring system of meaning informing how humans interpret the world; Cayre et al., 2018) about food consumption patterns and the role of technology. However, we agree with Foley et al. (2011) that we should not be locked into a single approach, which leads us to discuss how SI and AE could converge for a better future.

\section{Sustainable intensification}

\section{Historical perspective}

The term 'sustainable intensification' originated from development efforts that aimed to increase the productivity of sub-Saharan agriculture in the 1990s (Pretty, 1997). It was used in the context of increasing production from existing agricultural land in ways that lower environmental impact 
and do not lead to further land conversion or loss of 'undisturbed' natural ecosystems (Campbell et al., 2014). In the SI framework, changes in land-use intensity (higher yields, multiple cropping seasons, higher livestock stocking density) are accompanied by changes in the levels of biophysical and socioeconomic inputs to the land (e.g., labour, feed resources or capital). There are a number of illustrations showing that SI can have huge effects on domestic food budgets, social infrastructure, business development and the well-being of both the rural and urban populations (Pretty et al. 2011). Proponents of SI originally emphasised the importance of using local knowledge and developing agricultural methods suited to local conditions. Participation of smallholder farmers was considered crucial for the development of more productive technologies (Pretty, 1997). A wide range of bottom-up, integrated technologies was therefore used to conserve water and soils and to manage nutrient flows and pests. However, the term remained loosely defined, so that $\mathrm{SI}$ was subsequently firmly embraced by the industry and by a number of international organisations (Food and Agriculture Organisation (FAO), 2010; Campbell et al., 2014) for whom an increase in food demand is an inevitable response to population growth and dietary shifts towards more animal proteins.

In a recent assessment of the concept of $\mathrm{SI}$, many implementers of this framework indicated there is no clear difference between $\mathrm{SI}$ and 'traditional' intensification and modernisation practices (Petersen and Snapp, 2015). In practice, SI has long been 'narrowly' focused on production and has been criticised for lacking engagement with the key social principles of sustainability (Loos et al., 2014). According to these authors, focusing on the need to increase food production reflects a fundamental misunderstanding of the primary causes of food insecurity, that is, poverty and political and structural problems. Issues such as equity, access to food and food distribution would thus need to be prioritised before increases in production can improve food security. Recently, the SI framework has been more broadly conceived in a way that addresses dietary issues and improves equity of access to food. In this perspective, Garnett et al. (2013) do not consider SI as a 'business-asusual' food production with 'marginal' improvements in sustainability, but rather as a rethinking of a food system that reduces its environmental footprint supports rural economies and enhances human nutrition and animal welfare. Improvements in animal diets could for instance benefit animal welfare. However, there are potentially negative effects related to (i) more confined environments that affect the ability of the animals to express their natural behaviour and (ii) the risk of more animal health problems due to breeding for higher yields and growth rates (Röös et al., 2017; Huber, 2018).

\section{Sustainable intensification as an efficiency-oriented perspective}

One priority of $\mathrm{SI}$ is to close yield gaps (i.e. the difference between the actual and attainable yield on the basis of the genetic potential and optimal production conditions without yield limiting and reducing factors) to produce more food while using less land. Rao et al. (2015) discussed that the SI of forage-based systems is based on several intensification processes, including genetic intensification, that is, the deployment of productive livestock breeds, and the development and use of grass and legume cultivars selected because of their higher biomass production, nutritive value and persistence relative to native grasses. One key to the successful intensification of tropical forage-based systems is the adequate selection of fodder species, for instance, leucaena (Leucaena leucocephala, Lam.), a nitrogen-fixing shrub that can serve as the backbone of the system. Sustainable intensification of tropical forage-based systems is likely to increase their productivity (zu Ermgassen et al., 2018) while providing regulating ecosystem services, including a contribution to soil fertility, limitation of erosion, and climate regulation via $\mathrm{CO}_{2}$ sequestration. Integration of forage systems within cropping systems should enhance the coupling of carbon $(\mathrm{C})$ and nitrogen $(\mathrm{N})$ cycles in grasslands, cover-crops, and ley-farming systems, thus reducing the presence of reactive $\mathrm{N}$ in the soils and consequently, the risk of nitrate leaching and nitrous oxide emissions to the atmosphere (Lemaire et al., 2014). A large part of grassbased biomass and crop residues can be used for feeding ruminants. Genetic intensification of animals has frequently led to the use of high-yielding breeds. As an example, dairy producers in many places around the world view Holstein Friesian cattle as the ultimate cow for their farm to show their competence as dairy farmers. However, these animals are very dependent on controlled and optimal conditions; they can be vulnerable to climate change and are little adapted to feed on roughages (Phocas et al., 2016). As a consequence, production levels are often far below the attainable yield.

The search for increased efficiency requires precise adjustment of the diets of individual animals to their requirements. Precision livestock farming, by recording herbage biomass and quality and animal physiological and behavioural traits, offers new possibilities to efficiently monitor and manage highly productive livestock systems. According to Campbell et al. (2014), SI and climate smart agriculture are highly complementary, with SI being an essential lever for decreasing GHG emissions per unit of product (Röös et al., 2017). This efficiency-oriented perspective is in line with the logic of substituting cereals and soybean meal in ruminant diets with human-inedible resources. Crop residues such as culled Brussel sprouts, waste tomatoes and carrot pulp after juice extraction are used to supplement grazing animals or forages in areas where intensive vegetable production is common. Another innovative option consists of producing insects from food wastes and then using the insects as protein sources for livestock, including dairy cows (Stamer, 2015). Other humaninedible feed resources can be used, mainly for dry cows, growing heifers and small ruminants, including dried distillers grains with solubles, palm kernel cake or spineless cactus (Makkar, 2018). 


\section{Is sustainable intensification sustainable?}

Within the SI framework, the focus on improving resource use efficiency may, however, not necessarily lead to a reduction in the environmental footprint. This was observed in the Brazilian Amazon region, where more efficient agricultural systems were seen as profitable to farmers, which resulted in the expansion of the cultivated area and further deforestation (Lambin and Meyfroidt, 2011). The most efficient systems are not necessarily the most sustainable. Rodríguez-Ortega et al. (2017) compared three Mediterranean sheep farming systems by applying the emergy methodology that is based on the amount of direct and indirect materials and energy sources embodied in final products. Lamb meat production was 1.9 and 1.3 times more intensive and efficient, respectively, in a partially integrated mixed system than in a pasture-based sheep system but 5.1 times less sustainable as a result of lower self-sufficiency and renewability. One problem of crop-livestock systems that sell meat and cereal crops is that animals and crops frequently do not ecologically complement each other (Altieri et al., 2017). As a consequence, farmers keep on buying external chemical inputs. Conversely, in a suckler-cow farm network of the Charolais-area, organic farmers grow crops on farm to feed the cows and efficiently exploit the diversity of feed resources. These farms had the lowest GHG emissions and non-renewable energy consumption per ha, the lowest operational costs and the highest net income per worker (Veysset et al., 2014).

The definition of sustainability within the SI framework largely addresses the reduction of harmful effects, while little attention has been paid to producing positive environmental outcomes such as increasing the supply of clean water and the stocks of natural resources including fertile soils. Moreover, the focus is essentially utilitarian, that is, reducing harmful effects is done to ensure continuing agricultural production while remaining within 'planetary boundaries'. According to Struik and Kuyper (2017), the words 'sustainable' and 'intensification' are often not assigned equal weight. For instance, the Irish grassland-based dairy system developed according to the principles of $\mathrm{SI}$ causes biodiversity losses (Sullivan et al., 2010). The Food and Agriculture Organisation has advocated using an ecosystem services approach for $\mathrm{SI}$ (FAO, 2010). Given the classical trade-off between food production on the one side and many regulating and cultural services on the other, it is difficult to enhance all ecosystem services simultaneously. According to Smith (2013), SI should thus be regarded as a 'guiding principle in decisions about land-use, rather than as an end-point'. By interpreting SI as an inevitable response to population growth and the search for global food security, it is also only after productivity concerns are covered that most environmental and social issues are addressed. This limits the emergence of converging and transformative solutions that jointly account for productive and environmental issues and that meet the expectations of all types of stakeholders (Howe et al., 2014). Solutions are thus mostly sub-optimal for the environmental and social dimensions. For instance, Thorlakson et al. (2018) recently analysed how 449 companies in the food, textile and woodproducts sectors have adopted voluntary practices to improve the environmental and/or social management of their suppliers' activities. Half of these companies use some form of sustainable sourcing practices. However, these practices are limited in scope, with $71 \%$ covering only one or a few input materials, one quarter applying to only a single product line, and many primarily focusing on labour rights and compliance with national laws.

\section{Agroecology}

Historical perspective

The term 'agroecology' can be traced back to the 1930s and has been used to denote a scientific discipline, a set of agricultural practices, and a social movement that promotes culturally sensitive, socially fair and economically viable farming systems (Wezel et al., 2009). Until the 1960s, AE was only referred to as a scientific discipline. From the 1970s, AE gradually emerged as a movement in line with environmental movements that went against industrial agriculture creating greater specialisation and intensification. As a scientific discipline, AE applies ecological theory to the design and management of sustainable agroecosystems (Altieri, 2002; Wezel et al., 2009) or of the entire food system (Francis et al., 2003). It aims to stimulate natural processes to design agricultural systems that are weakly artificialised, productive, environmentally friendly and less dependent on chemical inputs. As a movement, $\mathrm{AE}$ counts thousands of researchers and practitioners, mainly in Latin America, where it does not work through any standard or certification system (Tittonell, 2014). It promotes traditional farming systems that sustain year-round yields through the use of agrobiodiversity. Diverse plant species and genetic resources and optimal interactions between system components (including between crops and livestock) are used to enhance agroecosystem functions rather than to introduce chemical inputs. Agroecology also promotes food sovereignty, local autonomy, and community control of land, water and genetic resources (Altieri et al., 2017). Farmer-to-farmer networks play a key role in the extension process and dissemination of knowledge (Rosset et al., 2011).

Despite the recent surge in the academic literature on $A E$, livestock farming systems have scarcely been considered in most agroecological thinking until recently. Disconnectedness from the land is probably the main problem threatening the sustainability of livestock farming. On the basis of a study conducted by Altieri (2002), who identified the key ecological processes to be optimised in agricultural systems, Dumont et al. (2013) proposed five principles as a guideline to implement site-specific combinations of agroecological practices in livestock farming systems: (i) achieve integrated animal health management, (ii) decrease the external inputs needed for production, (iii) decrease pollution by optimising the metabolic functioning of farming systems, (iv) enhance functional diversity within livestock farming systems to strengthen their resilience, and (v) preserve biological diversity by adapting 
management at farm and landscape scales. The application of these principles was shown to generate environmental and economic benefits that were quantified across a broad range of ruminant, pig, poultry, aquaculture, and integrated croplivestock systems. The extent to which the five principles were mobilised differed between production systems and their degree of intensification (Dumont et al., 2013; 2017).

\section{Agroecology promotes system redesign and can lead to win- wins between production and environmental goals}

Agroecology promotes system redesign and questions production goals. Within the French CIVAM network (Centres d'Initiatives pour Valoriser l'Agriculture et le Milieu rural), the target goal was to create added value from dairy production without always maximising outputs per animal or per unit area. This led to an increase in the use of grazed herbage at the expense of maize silage, as well as a reduction in the use of concentrate feeds. Limiting pesticides and insecticides through more complex crop rotations and an increase in grassland area at the farm level had various direct and indirect benefits on soils, water and biodiversity. Grasslands comprised a large proportion of grass-legume mixtures, and the grazing season was extended into late autumn and winter. Herd management was tailored to adapt animal requirements to resources by grouping calving periods. Inputs, feed costs and mechanisation costs were lower than in conventional systems from the same area. In spite of slightly lower milk production (-13\%), the gross margin was higher (+26\%). Greenhouse gas emissions were similar between the two systems, that is, $1.1 \mathrm{~kg} \mathrm{CO}$-eq/l but accounting for carbon sequestration in permanent grasslands and hedgerows led to a $14 \%$ reduction of net GHG emissions in the CIVAM compared with conventional dairy farms of the same area $(0.87$ v. $1.02 \mathrm{~kg} \mathrm{CO}$-eq/l; Duru and Therond, 2015).

One strength of agroecological systems lies in their selfsufficiency, which, through interacting with their environment and the recycling of on-farm wastes, can produce part of the resources needed for production. Self-sufficiency reduces dependency on erratic market prices but increases dependency on climatic conditions, for instance, summer droughts that can drastically reduce grassland biomass production. The potential of all-forage diets still needs to be demonstrated for productive dairy cattle breeds with high nutrient requirements. An example is the lower ovarian cyclicity during early lactation, which results in poor the reproductive performance of Holstein-Friesian and Montbéliarde cows in low-input systems, in spite of spring calving that aims to optimise grassland utilisation (Pires et al., 2015). Use of animal genotypes adapted to their environmental conditions, and access to pasture so that animals express their natural behaviour are essential principles of AE (Dumont et al., 2013; 2014), and are assumed to guarantee animal welfare. Beef cattle, dairy cattle, sheep and dairy goat farmers in agroecological systems did not establish strong priorities among breeding goals (i.e., between feed efficiency, animal health, reproduction, docility, product quality, etc.), but rather searched for animals with 'balanced' characteristics that are classically referred to as being 'robust' (Phocas et al., 2016).

High productivity levels can be achieved in tropical and Mediterranean silvopastoral systems that are based on highly diverse feed resources. In a Colombian dairy system, a tree-rich matrix allowed an increased stocking rate and increased milk production by $130 \%$ (Murgueitio et al., 2011) while completely eliminating the use of chemical fertilisers and contributing to climate regulation via the maintenance of soil organic matter and complex soil food webs. In tropical silvopastoral systems, the presence of trees within pastures benefits cattle welfare through less exposure to stressful climatic conditions and might increase milk yield (Paciullo et al., 2014). Observations in Latin America have emphasised that enhancing tree species diversity and structural complexity could increase system resilience after a hurricane (Altieri et al., 2017). An increased number of bee species in silvopastoral systems increased coffee production by an average of 5\% (Cardoso and Mendes, 2014). As trees mature, they also provide ecological corridors that connect wildlife-friendly habitats. In addition, trees provide timber and firewood materials to farmers, roots and bark for medicinal uses, green forage and pods for livestock, and fruits and honey for human consumption (Murgueitio et al., 2011). Overall, win-win solutions are the result of collective decisions rather than situations where only individual interests and power relations prevail; this has been shown in various temperate and tropical environments (Groot et al., 2010; Carmona-Torres et al., 2011; Howe et al., 2014).

How much can agroecology contribute to feeding the world? One of the main criticisms of $A E$ is that the productivity of agroecological systems is assumed to be lower than that of sustainably or traditionally intensified systems. This is denied by $A E$ advocates who stress the high long-term performance (Murgueitio et al., 2011) and higher resilience of tropical agroecological systems (Altieri et al., 2017). In addition, an increase in the complexity of crop rotations with temporary fodders, catch and cover-crops and traditional mixtures of crops and legumes (such as 'milpa' in Mexico or 'méteils' in France), mostly to the detriment of cereals, will likely enhance production and ecosystem services in both tropical and temperate environments (Altieri et al., 2017; Barbieri et al., 2017). There is indeed no a priori for system intensification in the agroecological framework, as previously illustrated by the example of French CIVAM farms, for which profitability was high for farmers (Dumont et al., 2013; Duru and Therond, 2015). One characteristic of most agroecological systems is that more time is required to supervise and observe the system. Consequently, labour productivity and productivity per unit area can be lower than in classically or sustainably intensified systems. This can be buffered by creating added value on the farm from higher-value products due to their better sensory quality or image, associated certification, and sometimes on-farm processing. Intrinsically, functional diversity plays a key role in the design of agroecological 
Table 1 A comparative summary of how sustainable intensification (SI) and agroecology (AE) have been applied to temperate and tropical ruminant systems

\begin{tabular}{|c|c|c|}
\hline & Sustainable intensification & Agroecology \\
\hline $\begin{array}{l}\text { Production per } \\
\text { unit area or per } \\
\text { animal }\end{array}$ & $\begin{array}{l}\text { Aims at increasing agricultural yields. Productivity is } \\
\text { assumed to increase through intensification of existing } \\
\text { farmland }\end{array}$ & $\begin{array}{l}\text { No a priori for intensification. Production can slightly decrease } \\
\text { per unitary component but at farm level, diversification of } \\
\text { production increases overall farm yields, ES and profitability to } \\
\text { farmers }\end{array}$ \\
\hline Use of inputs & $\begin{array}{l}\text { A key point is to increase nutrient use efficiency to minimise } \\
\text { negative impacts on the environment (no a priori for levels } \\
\text { of inputs required for production) }\end{array}$ & $\begin{array}{l}\text { A key point is to propose systems that are less dependent on } \\
\text { chemical inputs and use more on-farm produced inputs } \\
\text { through recycling }\end{array}$ \\
\hline $\begin{array}{l}\text { Link to local } \\
\text { environment }\end{array}$ & $\begin{array}{l}\text { Makes best use of environment potential, e.g., through } \\
\text { adapted cultivars/breeds. Inputs buffer environmental } \\
\text { fluctuations }\end{array}$ & $\begin{array}{l}\text { Weakly artificialised systems tied to their biophysical } \\
\text { environment and that use diversity to strengthen their } \\
\text { adaptive capacity and resilience }\end{array}$ \\
\hline $\begin{array}{l}\text { Biodiversity and } \\
\text { ecosystem } \\
\text { services (ES) }\end{array}$ & $\begin{array}{l}\text { SI entails increasing food production from existing farmland, } \\
\text { as part of a land sparing strategy. Up to a given stocking } \\
\text { density, regulating ES can be provided, but there is little or } \\
\text { no incentive for producing positive outcomes by using } \\
\text { biodiversity and ES }\end{array}$ & $\begin{array}{l}\text { Agroecology can be seen as part of a land sharing approach with } \\
\text { functional links with ES. It considers biodiversity as both a } \\
\text { resource (that provides ES to farmers) and an output. Scaling- } \\
\text { up AE would benefit from payment for environmental services }\end{array}$ \\
\hline $\begin{array}{l}\text { Animal selection } \\
\text { goals }\end{array}$ & $\begin{array}{l}\text { Selection on feed efficiency (to ensure efficient } \\
\text { transformation of feed into animal protein) or on residual } \\
\text { feed intake. Efficient animals emit less greenhouse gases } \\
\text { per unit of product }\end{array}$ & $\begin{array}{l}\text { Selection on a number of productive and adaptive traits (i.e., } \\
\text { breeding for robustness). Animal genetic resources and local } \\
\text { breeds offer opportunities to adapt animals to their local } \\
\text { environment }\end{array}$ \\
\hline $\begin{array}{l}\text { Role of } \\
\text { technology }\end{array}$ & $\begin{array}{l}\text { Technology is used to optimise the timing and quantity of } \\
\text { inputs applied. Anaerobic digestion recovers utilities from } \\
\text { wastes. SI and precision livestock farming are highly } \\
\text { complementary }\end{array}$ & $\begin{array}{l}\text { Technology facilitates the collection of individual-based } \\
\text { information and can be used to monitor every component of } \\
\text { the system to increase its overall efficiency. Technology needs } \\
\text { to remain accessible to smallholder farmers }\end{array}$ \\
\hline $\begin{array}{l}\text { Knowledge } \\
\text { transfer }\end{array}$ & $\begin{array}{l}\text { Mainly a top-down approach, though participation of } \\
\text { farmers was initially considered crucial for the } \\
\text { development and extension of productive technologies }\end{array}$ & $\begin{array}{l}\text { Mainly bottom-up, as agroecology places strong value on local } \\
\text { knowledge. Farmer-to-farmer networks also play a key role in } \\
\text { information transfer }\end{array}$ \\
\hline Labour & $\begin{array}{l}\text { Aims to increase labour productivity as part of efficiency } \\
\text { improvement }\end{array}$ & $\begin{array}{l}\text { More time to supervise and observe the system. Labour } \\
\text { productivity can thus be lower than in industrial or SI systems }\end{array}$ \\
\hline Market & $\begin{array}{l}\text { Non-differentiated products sold on the global market } \\
=>\text { A weak form of ecological modernisation largely based } \\
\text { on nutrient use efficiency and technology }\end{array}$ & $\begin{array}{l}\text { Selling in niche markets allows benefiting from the added value } \\
\text { created on the farm } \\
=>\text { A strong form of ecological modernisation largely based } \\
\text { on system re-conception and ecosystem services }\end{array}$ \\
\hline
\end{tabular}

ruminant systems so that they both benefit from and provide ecosystem services. Scaling-up agroecological livestock farming would thus benefit from payment for environmental services.

Functional diversity is assumed to increase system resilience, redundancy being the underlying property that supports mechanisms of stabilisation since the collapse of any species can be offset by another species with similar characteristics. The 'portfolio effect' states that communities with higher species richness are more likely to include the species that is best adapted to any given condition in fluctuating environments so that the number of species per se has a positive effect on system resilience (Dumont et al., 2017). Within herds, diversity of individual trade-offs between functions that was quantified in dairy goats (Puillet et al., 2010) and dairy cows (Ollion et al., 2016) does not increase herd milk production but is assumed to stabilise it under fluctuating environmental conditions. Abiotic and biotic interactions, including biogeochemical cycles and trophic interactions, lend ruminant systems further resilience properties (Dumont et al., 2017). The extent to which ecological processes benefit long-term system performances needs to be analysed for a fair evaluation of agroecological ruminant systems. So far, there has been a huge gap in terms of investments in research between traditionally or sustainably intensified systems and agroecological systems since the former have received the majority of governmental funding and almost the total investment in research by the private sector (Tittonell, 2014). A fair answer to the question of how much can $A E$ can contribute to feeding the world thus requires the opening of a vast research agenda for the animal science community (Dumont et al., 2014). In the AE paradigm, researchers no longer produce generic solutions or tools but consider farmer skills and knowledge (Altieri et al., 2017). This calls for a transdisciplinary approach of the research-development-innovation chain to bridge the gap between science and practice.

\section{How can sustainable intensification and agroecology converge for a better future?}

A comparative summary of the two frameworks is given in Table 1. It shows that SI and AE represent different forms of ecological modernisation of agriculture. Sustainable intensification is mainly related to a 'shallow sustainability' approach 
(Hill, 1998), also called a 'weak form of ecological modernisation' (Horlings and Marsden, 2011; Duru and Therond, 2015), that is largely based on an increase in nutrient use efficiency (Garnett, 2014). Agroecology goes beyond the use of alternative inputs and promotes system redesign. It can thus be seen as a 'deep-sustainability' approach (Hill, 1998), also called a 'strong form of ecological modernisation', in which ruminant farming systems benefit from functional diversity and provide ecosystem services (Horlings and Marsden, 2011; Duru and Therond, 2015). In this perspective, ruminant farming is more than just the production of meat and milk, so that a simple functional property (for instance, GHG emissions expressed in $\mathrm{kg} \mathrm{CO}_{2}$-eq/kg product) is an inadequate measure of system performance (Dumont et al., 2014; Makkar, 2018). In line with this dichotomy, different farmers' worldviews were shown to co-exist in Californian organic cropping systems (Guthman, 2000) and French Protected Designation of Origin cheese production areas (Cayre et al., 2018). On the one side, some farmers focus mainly on input substitution and use technology to achieve a high level of food production, while on the other small-scale farmers follow agroecological 'ideals' in more diversified systems.

\section{Convergence between sustainable intensification and agroecology requires moving towards a wider food system scale}

Agroecology and SI historically did not pay the same attention to the social dimensions of sustainability (Wezel et al., 2009; Loos et al., 2014). Agroecology and SI could now converge as some researchers investigating $\mathrm{SI}$ have proposed the adoption of a food-system transformation perspective (Garnett et al., 2013). Central to this is the conviction that excessive meat consumption is a leading cause of the environmental crisis. For instance, Popp et al. (2010) examined non- $\mathrm{CO}_{2} \mathrm{GHG}$ emissions from agriculture under different assumptions of food demand and concluded that reduced meat consumption would be far more effective than any technical mitigation measure. This goes in line with outputs from a recent meta-analysis (Aleksandrowicz et al., 2016). Consistently, most ongoing scenarios simulate a decline in animal protein consumption and limit livestock production to pasture and co-products from human food (e.g., van Zanten et al., 2016). However, some proponents of SI, including actors and lobbies from food and farming industry, and researchers, still highlight the short-term negative effects such options could have on livestock business and economic growth in the agricultural sector (Röös et al., 2017).

While both frameworks aim to optimise land-use at the global level, there are still different views on where food should be produced. Indeed, while enough food is produced globally there remains strong food security challenges. This mismatch emerges through the complex patterns of global trade in food products (Smith, 2013; Gordon et al., 2017). Integrated global markets have often been advocated by $\mathrm{SI}$ proponents (Röös et al., 2017). For instance, demographic shifts and economic development in emerging countries have stimulated EU exports, notably for the dairy and pork sectors.
By contrast, AE calls for new forms of regionally embedded agri-food systems, which implies rethinking market mechanisms. It has given priority to local autonomy and community control of land since the very beginning (Altieri, 2002; Rosset et al., 2011; Cardoso and Mendes, 2014). In addition, AE calls to strengthen links between producers and consumers. In Europe and North America, local production emerged to restore consumer confidence in food systems. In Europe, local production creates added value for high-quality products with a strong territorial identity. In developing countries, the local production aims to secure food sovereignty based on low-input production systems. As no space is available for agricultural land expansion, for instance, in South Asia and East Asia (Smith, 2013), local production will imply a search for methods to increase yield, an increase in cropping intensity (e.g., double or triple cropping within a year), and/or increased and more resilient production in complex silvopastoral systems. This can be achieved through the use of adapted crossbreeds or local breeds rather than the use of high-yielding livestock breeds that may be ill-adapted to climate change. Intensification efforts should also consider the social context and are made easier when innovations have been co-designed by farmers and NGO's involved in rural development from the start of the process (e.g. Kosgey et al., 2006 for small ruminant breeding programmes in the tropics).

Beyond closing yield gaps, meeting the projected demands of population growth calls for improving food distribution and access, as well as market infrastructure, which will require changing policies and global mechanisms that rule the food system (Foley et al., 2011). As reviewed by De Schutter and Vanloqueren (2011), market and political obstacles could be overcome through six policy principles: (i) focusing efforts on the needs of smallholders; (ii) redistributing public goods as part of food security policies; (iii) gaining a richer understanding of innovation that includes traditional knowledge; (iv) involving meaningful participation of smallholders in local programmes and nationwide policies; (v) using public procurement to speed the transition towards sustainable agriculture; and (vi) redefining performance criteria used to monitor agricultural projects beyond classical measures such as productivity per unit of land or water. This confirms that $\mathrm{SI}$ and $\mathrm{AE}$ cannot be considered from their biotechnical definition only and should further move towards a wider food system scale, encompassing productive, environmental and social dimensions.

\section{Use of new technologies is widespread in sustainable intensification and offers opportunities for scaling-up agroecology}

The application of new technologies has a different share within the SI and AE frameworks. Within SI, new technologies provide a foundation for the transition towards more efficient and intensified systems, for instance, through the optimal timing and amount of feed offered to the animals, nutrient recycling, early detection of livestock diseases, and alternative reproduction techniques (Food and Agriculture 
Organisation, 2011; Dumont et al., 2013; Garnett et al., 2013; Campbell et al., 2014). Makkar (2018) advocated the need to develop a business model around these technologies and to bring private companies on board. Through the $\mathrm{SI}$ framework, biotechnology and the use of genomic information have also found a new avenue to promote themselves as a solution to world hunger (Tittonell, 2014). The most recent example is the Bill and Melinda Gates Foundation funding a non-profit research alliance to select cows that are both more productive and resistant to heat stress, for instance by providing genomic tools for screening young animals that have the desired traits for a particular environment. Early detection of livestock diseases through precise animal monitoring would benefit animal welfare. More broadly, making appropriate use of digital sciences is likely to help in the gathering of individual-based data and the monitoring of every component of the system to increase its overall efficiency (Ingrand, 2018). Livestock farmers are indeed becoming increasingly reliant on new digital technologies and communication tools that increase knowledge dissemination and connections among actors. For instance, pastoralist communities in East Africa and Mongolia use smartphones as an early warning system for predicting forage availability in arid rangelands, which increases system longterm efficiency. The key issue for making digital science part of the agroecological transition is that it remains at a low cost and is thus accessible to smallholder farmers.

\section{Strict certifications could offer opportunities to boost sustainable intensification and agroecology}

Consumers and civil society pressures have led to increased adoption of sustainable practices by food companies (Thorlakson et al., 2018), which is likely to have some animal welfare and environmental benefits. Although varying across regions and socio-demographic characteristics of consumers, the willingness of consumers to pay for farm animal welfare is higher for beef and dairy cows than for pigs, poultry and aquaculture (Clark et al., 2017). This reveals the potential of labelling ruminant farming systems through strict welfare certifications so that citizens can develop their own system of consumption ethics (Dumont et al., 2014). Regarding environmental benefits, compliance with the Brazilian Forest Code was achieved thanks to increased transparency in the Brazilian cattle supply chain (Guéneau, 2018; zu Ermgassen et al., 2018). This increased compliance did not affect the productivity of beef and dairy farms. Success depended on the independent audit of slaughterhouses, to ensure they only purchased livestock from farms/municipalities in compliance with the Forest Code (zu Ermgassen et al., 2018). In Latin America, $\mathrm{AE}$, however, does not operate through any standard or certification system (Tittonell, 2014). Botreau et al. (2014) showed that it is possible to build a multicriteria evaluation tool that qualifies the compliance of mountain dairy systems with agroecological principles. By crossing agroecological principles with categories of state variables on which the fulfilment of these principles should have a positive effect, it becomes possible to identify a complete range of practice-based criteria accounting for ecological processes and interactions within a system. The criteria should be understood and acceptable by farmers and technical advisors and are specific to the mountain context (Botreau et al., 2014), as agroecological practices must be adapted to local conditions (Altieri, 2002). This methodology allows the comparison of mountain dairy farms and can thus lead to a strict and verifiable certification of agroecological systems.

\section{Conclusion}

Both $\mathrm{SI}$ and $\mathrm{AE}$ promote ways to reconcile natural resource management and food production in the long term. In spite of a common goal, $\mathrm{SI}$ and $\mathrm{AE}$ are underpinned by different values and worldviews about food consumption patterns, the role of technology and our relationship with nature. Historically, SI sees the increase in animal protein demand as inevitable and therefore focuses on increasing production efficiency as part of a land sparing strategy. Agroecology appears more open to dietary shifts towards less animal protein consumption to rebalance the whole food system and gives a key role to nature-based processes in the design of livestock farming systems. Sustainable intensification and $A E$ could, however, converge for a better future. Food-system transformation perspectives and attention on social justice have been recently integrated into the SI framework. As no space is available for agricultural land expansion in many areas, local production from agroecological systems also requires an increase in the productivity of ruminant systems. Intensification of agroecological systems should, however, be achieved differently than what occurred in industrial systems, by considering context specificities and farmer knowledge. Applying SI to industrial systems could be seen as a green-washing strategy because it leads only to a weak form of ecological modernisation. Conversely, identifying first the key ecological processes to be optimised, is more likely to lead in the direction of a strong form of ecological modernisation assumed here to be more desirable.

\section{Acknowledgements}

The authors are grateful to two anonymous referees for their challenging comments and to Marc Benoit (INRA Theix) for fruitful discussions. B.D. was funded by INRA - Ecosystem Services Metaprogramme project AESIDS: Agroecology and Ecosystem Services in Indian Dairy Systems.

\section{Declaration of interest}

The authors declare no competing interests regarding this publication.

\section{Ethics statement}

Section is irrelevant for this literature review.

Software and data repository resources

No new software or database were generated as part of the outcomes of this literature review. 


\section{References}

Aleksandrowicz L, Green R, Joy EJM, Smith P and Haines A 2016. The impacts of dietary change on greenhouse gas emissions, land use, water use, and health: A systematic review. PLoS ONE 11, e0165797.

Altieri MA 2002. Agroecological principles and strategies for sustainable agriculture. In Agroecological innovations: increasing food production with participatory development (ed. NT Uphoff), pp. 40-46. Earthscan, London, UK.

Altieri MA, Nicholls $\mathrm{Cl}$ and Montalba R 2017. Technological approaches to sustainable agriculture at a crossroads: an agroecological perspective. Sustainability 9, 349.

Animal Task Force 2013. Research \& innovation for a sustainable livestock sector in Europe. An Animal Task Force white paper, April 2013. Retrieved on 27 April 2018 from http://www.animaltaskforce.eu/Portals/0/ATF/horizon2020/ATF $\% 20$ white $\% 20$ paper\%20Research $\% 20$ priorities $\% 20$ for $\% 20$ a $\% 20$ sustainable $\% 20$ livestock\%20sector\%20in\%20Europe.pdf.

Barbieri P, Pellerin S and Nesme T 2017. Comparing crop rotations between organic and traditional farming. Scientific Reports 7, 13761.

Botreau R, Farruggia A, Martin B, Pomiès D and Dumont B 2014. Towards an agroecological assessment of dairy systems: proposal for a set of criteria suited to mountain farming. Animal 8, 1349-1360.

Campbell BM, Thornton P, Zougmoré R, van Asten P and Lipper L 2014. Sustainable intensification: What is its role in climate smart agriculture? Current Opinion in Environmental Sustainability 8, 39-43.

Cardoso IM and Mendes F 2014. People managing landscapes: agroecology and social processes. In Proceedings of the FAO International Symposium on Agroecology for Food Security and Nutrition, 18-19 September 2014, Rome, Italy, pp. 73-87.

Carmona-Torres C, Parra-López C, Groot JCJ and Rossing WAH 2011. Collective action for multi-scale environmental management: achieving landscape policy objectives through cooperation of local resource managers. Landscape and Urban Planning 103, 24-33.

Cayre P, Michaud A, Theau JP and Rigolot C 2018. The coexistence of multiple worldviews in livestock farming drives agroecological transition. A case study in French Protected Designation of Origin (PDO) cheese mountain areas. Sustainability 10, 1097.

Chaudhary A and Kastner T 2016. Land use biodiversity impacts embodied in international food trade. Global Environmental Change 38, 195-204.

Clark B, Stewart GB, Panzone LA, Kyriazakis I and Frewer LJ 2017. Citizens, consumers and farm animal welfare: a meta-analysis of willingness-to-pay studies. Food Policy 68, 112-127.

De Schutter 0 and Vanloqueren G 2011. The New Green Revolution: how twenty-first-century science can feed the world. The Solutions Journal 2, 33-44. Dumont B, Fortun-Lamothe L, Jouven M, Thomas M and Tichit M 2013. Prospects from agroecology and industrial ecology for animal production in the $21^{\text {st }}$ century. Animal 7, 1028-1043.

Dumont B, González-García E, Thomas M, Fortun-Lamothe L, Ducrot C, Dourmad JY and Tichit M 2014. Forty research issues for the redesign of animal production systems in the $21^{\text {st }}$ century. Animal 8, 1382-1393.

Dumont B, Jouven M, Bonaudo T, Botreau R and Sabatier R 2017. A framework for the design of agroecological livestock farming systems. In Agroecological practices for sustainable agriculture - principles, applications, and making the transition (ed. A Wezel), pp. 263-291. World Scientific Publishing Europe Ltd, London, UK.

Duru $\mathrm{M}$ and Therond 0 2015. Livestock system sustainability and resilience in intensive production zones: which form of ecological modernization? Regional Environmental Change 15, 1651-1665.

Foley JA, Ramankutty N, Brauman KA, Cassidy ES, Gerber JS, Johnston $M_{t}$ Mueller ND, O'Connell C, Ray DK, West PC, Balzer C, Bennett EM, Carpenter SR, Hill J, Monfreda C, Polasky S, Rockström J, Sheehan J, Siebert S, Tilman D and Zaks DPM 2011. Solutions for a cultivated planet. Nature 478, 337-342.

Food and Agriculture Organisation 2010. Sustainable crop production intensification through an ecosystem approach and an enabling environment: capturing efficiency through ecosystem services and management. Committee on Agriculture. Twenty-second session, Rome, 16-19 June 2010. FAO, Rome, Italy. Food and Agriculture Organisation 2011. Successes and failures with animal nutrition practices and technologies in developing countries. In Proceedings of the FAO Electronic Conference, 1-30 September 2010, FAO, Rome, Italy, Retrieved on 27 April 2018 from http://www.fao.org/docrep/014/i2270e/ i2270e00.pdf.
Fouilleux E, Bricas N and Alpha A 2017. 'Feeding 9 billion people': global food security debates and the productionist trap. Journal of European Public Policy 24, 1658-1677.

Francis C, Lieblein G, Gliessman S, Breland TA, Creamer N, Harwood R, Salomonsson $L$, Helenius $L$, Rickerl D, Salvador R, Wiedenhoeft M, Simmons $S$, Allen P, Altieri M, Flora C and Poincelot R 2003. Agroecology: the ecology of food systems. Journal of Sustainable Agriculture 22, 99-118.

Garnett T 2014. Three perspectives on sustainable food security: efficiency, demand restraint, food system transformation. What role for life cycle assessment? Journal of Cleaner Production 73, 10-18.

Garnett T, Appleby MC, Balmford A, Bateman IJ, Benton TG, Bloomer P, Burlingame B, Dawkins M, Dolan L, Fraser D, Herrero M, Hoffman I, Smith $P$, Thornton PK, Toulmin C, Vermeulen SJ and Godfray HC 2013. Sustainable intensification in agriculture: Premises and policies. Science 341, 33-34.

Gerber PJ, Steinfeld H, Henderson B, Mottet A, Opio C, Dijkman J, Falcucci A and Tempio $G$ 2013. Tackling climate change through livestock - a global assessment of emissions and mitigation opportunities. FAO, Rome, Italy. Retrieved 27 April 2018 from http://www.fao.org/3/a-i3437e.pdf.

Gordon LJ, Bignet V, Crona B, Henriksson PJG, Van Holt T, Jonell M, Lindahl T, Troell M, Barthel S, Deutsch L, Folke C, Haider LJ, Rockström J and Queiroz C 2017. Rewiring food systems to enhance human health and biosphere stewardship. Environmental Research Letters 12, 100201.

Groot JCJ, Jellema A and Rossing WAH 2010. Designing a hedgerow network in a multifunctional agricultural landscape: Balancing trade-offs among ecological quality, landscape character and implementation costs. European Journal of Agronomy 32, 112-119.

Guéneau S 2018. Neoliberalism and the emergence of private sustainability initiatives: the case of the Brazilian cattle value chain. Business Strategy and the Environment 27, 240-251.

Guthman J 2000. Raising organic: an agro-ecological assessment of grower practices in California. Agriculture and Human Values 17, 257-266.

Hill SB 1998. Redesigning agroecosystems for environmental sustainability: a deep systems approach. Systems Research and Behavioral Science 15, 391-402. Horlings LG and Marsden TK 2011. Towards the real green revolution? Exploring the conceptual dimensions of a new ecological modernisation of agriculture that could 'feed the world'. Global Environmental Change 21, 441-452.

Howe C, Suich H, Vira B and Mace GM 2014. Creating win-wins from trade-offs? Ecosystem services for human well-being: a meta-analysis of ecosystem service trade-offs and synergies in the real world. Global Environmental Change 28, 263-275.

Huber K 2018. Invited review: resource allocation mismatch as pathway to disproportionate growth in farm animals - prerequisite for a disturbed health. Animal 12, 528-536.

Ingrand S 2018. Opinion paper: 'monitoring te salutant.' combining digital sciences and agro-ecology to design multi-performant livestock farming systems. Animal 12, 2-3.

Kosgey LS, Baker RL, Udo HMJ and Van Arendonk JAM 2006. Successes and failures of small ruminant breeding programmes in the tropics: a review. Small Ruminant Research 61, 13-28.

Lambin EF and Meyfroidt P 2011. Global land use change, economic globalization, and the looming land scarcity. Proceedings of the National Academy of Sciences of the USA 108, 3465-3472.

Lemaire G, Franzluebbers A, de Faccio Carvalho PC and Dedieu B 2014. Integrated crop-livestock systems: strategies to achieve synergy between agricultural production and environmental quality. Agriculture, Ecosystems and Environment 190, 4-8.

Loos J, Abson DJ, Chappell MJ, Hanspach J, Mikulcak F, Tichit M and Fischer J 2014. Putting meaning back into 'sustainable intensification'. Frontiers in Ecology and Environment 12, 356-361.

Makkar HPS 2018. Review: feed demand landscape and implications of food-not feed strategy for food security and climate change. Animal (doi:10.1017/ S175173111700324X, Published online 4 December 2017.

Murgueitio E, Calle Z, Uribe F, Calle A and Solorio B 2011. Native trees and shrubs for the productive rehabilitation of tropical cattle ranching lands. Forest Ecology and Management 261, 1654-1663.

Ollion E, Ingrand S, Delaby L, Trommenschlager JM, Colette-Leurent S and Blanc F 2016. Assessing the diversity of trade-offs between life functions in early lactation dairy cows. Livestock Science 183, 98-107. 
Paciullo DSC, Pires MFA, Aroeira LJM, Morenz MJF, Maurício RM, Gomide CAM and Silveira SR 2014. Sward characteristics and performance of dairy cows in organic grass-legume pastures shaded by tropical trees. Animal 8, 1264-1271. Petersen B and Snapp S 2015. What is sustainable intensification? Views from experts. Land Use Policy 46, 1-10.

Phocas F, Belloc C, Bidanel J, Delaby L, Dourmad JY, Dumont B, Ezanno P, Fortun-Lamothe L, Foucras G, Frappat B, González-García E, Hazard D, Larzul C, Lubac S, Mignon-Grasteau S, Moreno CR, Tixier-Boichard M and Brochard M 2016. Review: Towards the agroecological management of ruminants, pigs and poultry through the development of sustainable breeding programs: I- Selection goals and criteria. Animal 10, 1749-1759.

Pires JAA, Chilliard Y, Delavaud C, Rouel J, Pomies D and Blanc F 2015. Physiological adaptations and ovarian cyclicity of Holstein and Montbeliarde cows under two low-input production systems. Animal 9, 1986-1995.

Popp A, Lotze-Campen H and Bodirsky B 2010. Food consumption, diet shifts and associated non- $\mathrm{CO}_{2}$ greenhouse gases from agricultural production. Global Environmental Change 20, 451-462.

Pretty JN 1997. The sustainable intensification of agriculture. Natural Resources Forum 21, 247-256.

Pretty JN, Toulmin C and Williams S 2011. Sustainable intensification in African agriculture. International. Journal of Agricultural Sustainability 9, 5-24.

Puillet L, Martin O, Sauvant D and Tichit M 2010. An individual-based model simulating goat response variability and long-term herd performance. Animal 4, 2084-2098.

Rao I, Peters M, Castro A, Schultze-Kraft R, White D, Fisher M, Miles J, Lascano C, Blümmel M, Bungenstab D, Tapasco J, Hyman G, Bolliger A, Paul B, Van der Hoek R, Maass B, Tiemann T, Cuchillo M, Douxchamps S, Villanueva C, Rincón Á, Ayarza M, Rosenstock T, Subbarao G, Arango J, Cardoso J, Worthington M, Chirinda N, Notenbaert A, Jenet A, Schmidt A, Vivas N, Lefroy R, Fahrney K, Guimarães E, Tohme J, Cook S, Herrero M, Chacón M, Searchinger T and Rudel T 2015. LivestockPlus - the sustainable intensification of forage-based agricultural systems to improve livelihoods and ecosystem services in the tropics. Tropical Grasslands 3, 59-82.

Rodríguez-Ortega T, Oteros-Rozas E, Ripoll-Bosch R, Tichit M, Martín-López B and Bernués A 2014. Applying the ecosystem services framework to pasturebased livestock farming systems in Europe. Animal 8, 1361-1372.

Rodríguez-Ortega T, Bernués A, Olaizola AM and Brown MT 2017. Does intensification result in higher efficiency and sustainability? An emergy analysis of Mediterranean sheep-crop farming systems. Journal of Cleaner Production 144 171-179.
Röös E, Bajželj B, Smith P, Patel M, Little D and Garnett T 2017. Greedy or needy? Land use and climate impacts of food in 2050 under different livestock futures. Global Environmental Change 47, 1-12.

Rosset PM, Machín Sosa B, Roque Jaime AM and Ávila Lozano DR 2011. The Campesino-to-Campesino agroecology movement of ANAP in Cuba: social process methodology in the construction of sustainable peasant agriculture and food sovereignty. Journal of Peasant Studies 38, 161-191.

Smith $P$ 2013. Delivering food security without increasing pressure on land. Global Food Security 2, 18-23.

Stamer A 2015. Insect proteins-a new source for animal feed. EMBO reports 16, 676-680.

Struik PC and Kuyper TW 2017. Sustainable intensification in agriculture: the richer shade of green. A review. Agronomy for Sustainable Development 37, 39.

Sullivan CA, Skeffington MS, Gormally MJ and Finn JA 2010. The ecological status of grasslands on lowland farmlands in western Ireland and implications for grassland classification and nature value assessment. Biological Conservation 143, 1529-1539.

Thorlakson T, de Zegher JF and Lambin EF 2018. Companies' contribution to sustainability through global supply chains. Proceedings of the National Academy of Sciences of the USA 115, 2072-2077.

Tittonell P 2014. Ecological intensification of agriculture - sustainable by nature. Current Opinion in Environmental Sustainability 8, 53-61.

Tscharntke T, Clough Y, Wanger TC, Jackson L, Motzke I, Perfecto I, Vandermeer $J$ and Whitbread A 2012. Global food security, biodiversity conservation and the future of agricultural intensification. Biological Conservation 151, 53-59.

van Zanten HHE, Meerburg BG, Bikker P, Herrero M and de Boer IJM 2016. Opinion paper: The role of livestock in a sustainable diet: a land-use perspective. Animal 10, 547-549.

Veysset $P$, Lherm M, Bébin D and Roulenc M 2014. Mixed crop-livestock farming systems: a sustainable way to produce beef? Commercial farm results, questions and perspectives. Animal 8, 1218-1228.

Wezel A, Bellon S, Doré T, Francis C, Vallod D and David C 2009. Agroecology as a science, a movement and a practice. A review. Agronomy for Sustainable Development 29, 503-515.

zu Ermgassen EKHJ, de Alcântara MP, Balmford A, Barioni L, Beduschi Neto $F$, Bettarello MMF, de Brito G, Carrero GC, de AS Florence E, Garcia E, Gonçalves ET, da Luz CT, Mallman GM, Strassburg BBN, Valentim JF and Latawiec A 2018. Results from on-the-ground efforts to promote sustainable cattle ranching in the Brazilian Amazon. Sustainability 10, 1301. 